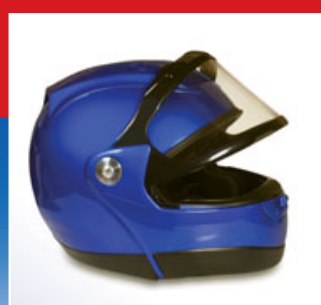

\title{
Do fiber-reinforced polymer composites provide environmentally benign alternatives? A life-cycle-assessment-based study
}

\author{
Joost R. Duflou, Yelin Deng, Karel Van Acker, and Wim Dewulf
}

This article summarizes the energy savings and environmental impacts of using traditional and bio-based fiber-reinforced polymer composites in place of conventional metal-based structures in a range of applications. In addition to reviewing technical achievements in improving material properties, we quantify the environmental impacts of the materials over the complete product life cycle, from material production through use and end of life, using life-cycle assessment (LCA).

\section{Introduction}

Fiber-reinforced polymers (FRPs) are among the most widely produced categories of composite materials. ${ }^{1}$ Initially developed decades ago for the aerospace industry, these composites have spread to a wide range of applications, including automobiles, shipbuilding, circuit boards, construction materials, and household equipment (Figure 1). Because of their high stiffness, strength, and fatigue resistance, as well as their low density and ease of shaping, FRPs provide attractive alternatives to steel and nonferrous metals in structural applications. ${ }^{3}$ Recently, researchers have also explored bio-based FRPs, in which either the polymer matrix or the reinforcement fibers, or both, come from renewable resources. ${ }^{4}$

This article discusses the environmental impacts of transitioning from conventional materials to FRPs, as determined by life-cycle assessment (LCA). The net change depends on many processes throughout the life cycle of an envisaged application, including energy and mass flows as well as emissions and waste (Figure 2). Because FRP components are often lighter than their traditional counterparts, it is important to compare their impacts on a functionally equivalent basis.

\section{Traditional and bio-based fiber-reinforced polymers Fiber materials}

The best-established FRPs are glass-fiber-reinforced polymers (GFRPs), which are used in a variety of products, including printed circuit boards, tanks and pipes, car body panels, and wind turbine blades. The high melting temperature of glass (glass-fiber production occurs at $\sim 1550^{\circ} \mathrm{C}$ ) makes energy intensity the major environmental issue. ${ }^{5}$

Carbon-fiber-reinforced polymers (CFRPs) use carbon fibers that require considerable energy to produce, because they are made by pyrolysis at $1000-1400^{\circ} \mathrm{C}$ for high-modulus fibers or at $1800-2000^{\circ} \mathrm{C}$ for high-strength fibers. ${ }^{6}$ The energy expenditure has decreased, however, as production methods have evolved. $^{7-9}$

One promising class of carbon fibers, carbon nanofibers, requires more energy to produce, depending on the feedstock and other details, and generally gives low yields of $15-50 \% .^{10}$ A major concern for nanofibers is their potential human toxicity and ecotoxicity. Although they are probably less harmful in a matrix, free particles in the nanometer size range raise health and environmental concerns because of their large surface-areato-mass ratios and their ability to penetrate biological cells. ${ }^{11}$ 


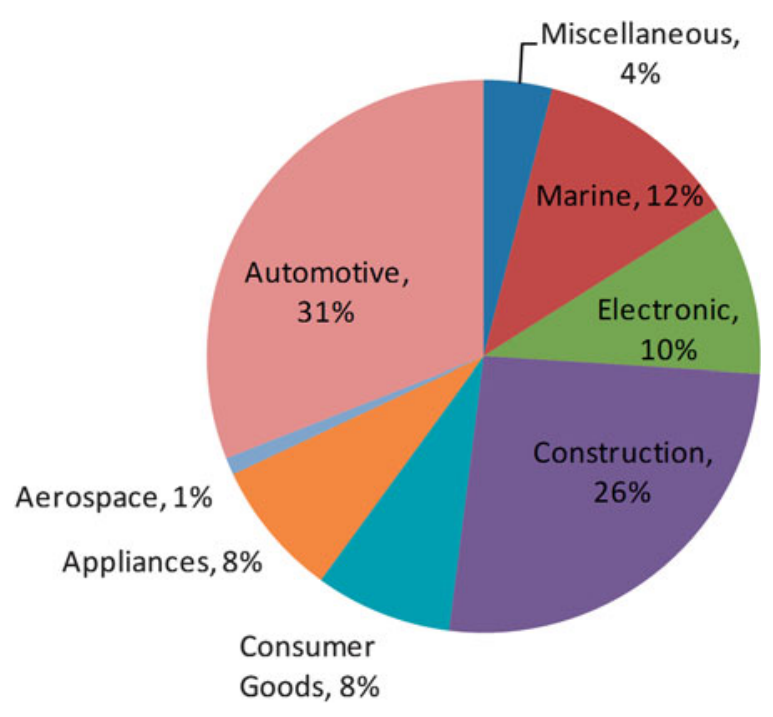

Figure 1. Market share distribution of fiber-reinforced polymers (FRPs) by application. ${ }^{2}$

Carbon nanofibers could hence exhibit toxic properties similar to those of asbestos, but because of a lack of data, this effect has not yet been taken into account in LCA studies.

Natural-fiber-reinforced polymers (NFRPs), which incorporate animal-, mineral-, and plant-based fibers, can be used as reinforcements in composites. Little information is available on animal- and mineral-based fibers, but properties of plant-based fibers and composites reinforced with such fibers are well-documented. ${ }^{12-14}$ In general, the tensile strength and Young's modulus of widely used plant-based fibers (e.g., hemp, flax fibers) are lower than those of commonly used glass fibers. However, because their density $\left(\sim 1.4 \mathrm{~g} / \mathrm{cm}^{3}\right)$ is less than that of glass fibers $\left(\sim 2.5 \mathrm{~g} / \mathrm{cm}^{3}\right)$, plant-based fibers have a higher specific strength and modulus, making them attractive when weight reduction is critical. ${ }^{14}$

\section{Matrix materials}

Matrix materials for FRPs conventionally include thermosets, such as epoxy, unsaturated polyester, and phenolic resins, but thermoplastic matrix materials are also used for processing and recyclability reasons. Energy consumption occurs during the many synthesis steps, involving first extraction of mineral

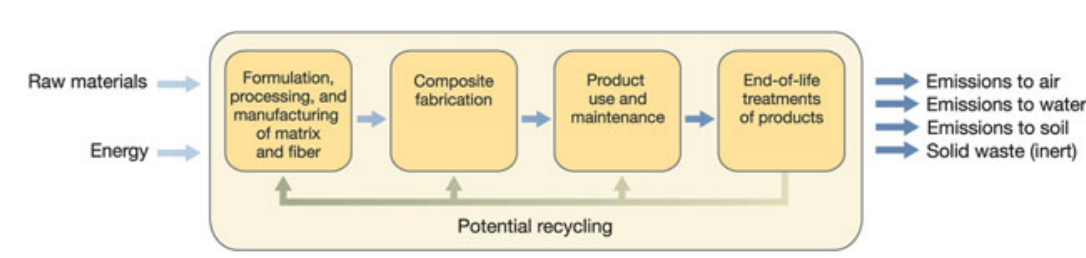

Figure 2. Generic life-cycle phases of a composite component. Each phase might require resource inputs and might create other impacts. oil, then separation and refining, and finally characterization and polymerization.

Common bio-based matrix materials include modified starch, ${ }^{15,16}$ bio-based polyester [e.g., poly(lactic acid) (PLA) ${ }^{17,18}$ ], microbial synthesis polymers [e.g., polyhydroxyalkanoates (PHAs $\left.)^{17,18}\right]$, and polymers synthesized from functionalized vegetable oil [e.g., epoxidized linseed oil (ELO) $)^{19-26}$ ].

\section{Comparing materials using life-cycle assessment}

LCA evaluates potential environmental costs or benefits for a particular application, quantifying the many tradeoffs between different life phases. This article explores three impact measures. First, cumulative energy demand (CED) can be an effective screening indicator for overall environmental impact, because energy consumption, especially fossil-fuel consumption, is a major driver for several environmental impact categories. ${ }^{27}$ Second, greenhouse-gas (GHG) emissions and the climate change to which they contribute are among the most significant environmental issues. ${ }^{28}$ The units for measuring greenhouse gas emissions are $\mathrm{CO}_{2}$ equivalents $\left(\mathrm{CO}_{2} \mathrm{e}\right)$, which account for the different global-warming potentials of different gases. The third assessment measure, used when sufficient data are available, consists of aggregate environmental impact scores, expressed in ecopoints. Unless stated otherwise, the ecopoint values discussed in this article were calculated using the impact-assessment method $\mathrm{ReCiPe}^{29}$ and are given in milli-ecopoints (mPt).

A per-kilogram basis provides a clear picture of the environmental intensity of raw materials production, but would inappropriately penalize the lighter polymer composites in components where stiffness, strength, or both determine the amount of material used. Instead, other indicators (see online supplementary materials) have been proposed that yield minimum weight or minimum environmental impact under constraints such as equal stiffness, ${ }^{30-33}$ equal strength, ${ }^{33,34}$ equal weight and geometry, ${ }^{35,36}$ or metrics based on measurements on specific components. ${ }^{37-39}$

\section{Materials impacts at different life-cycle phases Production phase}

Table I lists CED values, GHG emissions, and ecopoints associated with production of several matrix and fiber materials, as well as manufacturing methods for composites. In some cases, different production methods show widely varying environmental impacts. For example, making the PHA matrix material poly( $\beta$-hydroxybutyrate) (PHB) by fermentation releases energy, with a negative CED of $-22.7 \mathrm{MJ} / \mathrm{kg}$ and $\mathrm{GHG}$ emissions of $-3.1(\mathrm{~kg}$ of $\left.\mathrm{CO}_{2} \mathrm{e}\right) / \mathrm{kg}$, whereas PHB obtained from corn starch has a large positive CED $(38.6 \mathrm{MJ} / \mathrm{kg})$ but essentially zero GHG emissions. ${ }^{40}$

Table II provides an overview of LCA studies on production-phase environmental impacts 
Table I. Cumulative energy demand (CED), greenhouse-gas (GHG) emissions, and ecopoints for various materials and production processes.

\begin{tabular}{|c|c|c|c|}
\hline Material & CED (MJ/kg) & $\begin{array}{l}\mathrm{GHG}(\mathrm{kg} \text { of } \\
\left.\mathrm{CO}_{2} \mathrm{e} / \mathrm{kg}\right)\end{array}$ & Ecopoints (mPt/kg) \\
\hline \multicolumn{4}{|l|}{ Matrix } \\
\hline Liquid epoxy & $76-137^{41-43}$ & $4.7-8.1^{42,43}$ & $734^{44}$ \\
\hline Polyester (PES), unsaturated & $62.8-78^{41,42,45}$ & $2.3^{42}$ & $644^{44}$ \\
\hline Polypropylene (PP) & $73.4^{43}$ & $2.0^{43}$ & $276^{44}$ \\
\hline Mater- $\mathrm{Bi}^{\circledR}$-modified starch & $54.8^{46}$ & $1.3^{46}$ & $275^{44}$ \\
\hline $\begin{array}{l}\text { Ingeo } 2009^{\mathrm{TM}} \text { poly(lactic acid) } \\
\text { (PLA) }\end{array}$ & $67.8^{47}$ & $1.3^{47}$ & $312^{44}$ \\
\hline Polyhydroxyalkanoates (PHAs) & $59-107^{48-50}$ & $0.7-4.4^{48-50}$ & NA \\
\hline $\begin{array}{l}\text { Epoxidized linseed oil (ELO) } \\
\text { monomer }\end{array}$ & $19^{51}$ & $1.2^{51}$ & NA \\
\hline \multicolumn{4}{|l|}{ Reinforcement } \\
\hline $\begin{array}{l}\text { Polyacrylonitrile- (PAN-) based } \\
\text { carbon fiber (CF) }\end{array}$ & $286-704^{8,9,41}$ & $22.4-31^{8,9}$ & $833^{44}$ \\
\hline Carbon nanofiber (CNF) & $654-1807^{10}$ & $70-92^{10}$ & NA \\
\hline Glass fiber (GF) & $45^{5}$ & $2.6^{5}$ & $264^{44}$ \\
\hline Flax fiber, with irrigation & $9.6-12.4^{35,52}$ & $0.4^{52}$ & $350^{44}$ \\
\hline Hemp fiber, without irrigation & $6.8-13.2^{52,53}$ & $1.6^{52}$ & NA \\
\hline Jute fiber & $3.8-8.0^{54}$ & $1.3-1.9^{54}$ & NA \\
\hline Sugarcane bagasse & $11.7^{37}$ & NA & NA \\
\hline \multicolumn{4}{|c|}{ Manufacturing Processes for Selected Composites } \\
\hline Sheet molding compound (SMC) & $3.5-3.8^{8,41}$ & NA & $13^{44}$ \\
\hline Resin transfer molding (RTM) & $12.8^{30}$ & NA & $46^{44}$ \\
\hline Pultrusion & $3.1^{41}$ & NA & $11^{44}$ \\
\hline Autoclave & $21.9^{30}$ & NA & NA \\
\hline Injection molding & $21.1-29.9^{40,43}$ & $0.5-1.2^{40,43}$ & $126^{44}$ \\
\hline
\end{tabular}

NA, not available.

of different products made of composites, compared to their counterparts based on traditional materials. The values of CED and GHG emissions for matrixes and reinforcements in Table II do not fully agree with those in Table I because they were derived from different sources. Nevertheless, the trends are the same. Both GFRPs and CFRPs have been proposed as replacements for steel and aluminum in structural components. However, whereas GFRPs show consistently lower productionphase CED values and GHG emissions than either steel or aluminum, CFRPs generally score significantly worse than the metals.

\section{Use phase}

In the use phase, the impact of composite products is typically indirect. For example, FRPs are more durable than many traditional materials, such as steel and concrete, because they resist corrosion and fatigue better. ${ }^{1}$ According to a study performed by the Rotterdam city government, bridges made from CFRPs or GFRPs need no additional resources for maintenance. In contrast, for concrete or steel bridges, $5 \%$ of the initial materials for construction generally have to be replaced after 50 years. ${ }^{57}$ However, no quantitative data on the environmental impact of the maintenance of FPR components could be found in the literature.

In dynamic systems, such as vehicles, FRPs are used to achieve lightweight structures, thus reducing fuel consumption and related environmental impacts. Consequently, transportation systems are their major application, with automotive, aerospace, and marine uses representing $44 \%$ of total FRP consumption (see Figure 1). GFRPs are already used for decorative, nonstructural, and semistructural parts in cars, ${ }^{58,59}$ railway vehicles,${ }^{60}$ ships, ${ }^{61}$ and aircraft. ${ }^{62}$

Substituting natural fibers for glass fibers in automotive applications has also drawn significant interest. ${ }^{63-70}$ Compared to similar combinations based on glass fibers, NFRPs have lower costs, weights, and environmental impacts for functionally equivalent solutions including door panels, car interiors, package trays, and rear shelves. ${ }^{71}$ Shifting from glass to natural fibers has been reported to save $22-27 \%$ in weight. ${ }^{72}$

For structural parts in vehicles, which are currently made from steel or aluminum, CFRPs (e.g., carbon-fiber-reinforced epoxy or polypropylene) have been proposed as substitutes, because CFRPs can satisfy severe structural requirements while providing significant weight reductions..$^{58}$ Examples include the early "body-in-white" (BIW) stage of automobile manufacturing (consisting of the unpainted sheet metal frame of the vehicle), ${ }^{73-76}$ railway carriage structures, ${ }^{77}$ vertical stabilizers and fin boxes in aircraft, ${ }^{78}$ and ship hulls. ${ }^{79,80}$ Weight reductions of $50-70 \%$ can be anticipated if CFRPs are used in place of conventional, metal-based components.

In addition to such primary weight savings, secondary weight savings, known as mass decompounding, are also expected. For example, a lightweight body requires a lighter chassis, lighter brakes, a less powerful power train, and so on. Secondary savings of an additional $0.5-1.5 \mathrm{~kg}$ per kilogram of primary savings have been reported. ${ }^{8,58,81,82}$

Fuel consumption of a vehicle is determined by many factors (e.g., weight, shape, and route characteristics) and is therefore hard to estimate absolutely. However, other factors being equal, fuel consumption is proportional to vehicle mass for cars, ${ }^{83}$ trains, ${ }^{77}$ and aircraft. ${ }^{84}$ For ships, the 
Table II. Summary of life-cycle assessment (LCA) studies for fiber-reinforced polymers (FRPs) in the production phase.

\begin{tabular}{|c|c|c|c|c|c|}
\hline Product & Composite material & $\begin{array}{c}\text { Replaced traditional } \\
\text { material }\end{array}$ & Change in weight & $\begin{array}{l}\text { Change in cumulative } \\
\text { energy demand }\end{array}$ & $\begin{array}{l}\text { Change in greenhouse- } \\
\text { gas emissions }\end{array}$ \\
\hline \multirow[t]{4}{*}{ Bridge $^{38, \mathrm{a}}$} & \multirow[t]{4}{*}{ GF/PES pultruded } & Structural steel & $-33 \%$ & $-57 \%$ & \multirow[t]{4}{*}{ NA } \\
\hline & & Stainless steel & $-28 \%$ & $-68 \%$ & \\
\hline & & Concrete & $-85 \%$ & $-62 \%$ & \\
\hline & & Aluminum & $+25 \%$ & $-56 \%$ & \\
\hline Car side door ${ }^{39}$ & Hemp/EP & $A B S$ & $-27 \%$ & $-45 \%$ & $-15 \%$ \\
\hline Under-floor pan ${ }^{35}$ & Flax/PP & GF/PP & 0 & $-14 \%$ & NA \\
\hline Rotor blade ${ }^{36}$ & Flax/EP & CF/EP & 0 & $-50 \%$ & $-45 \%$ \\
\hline Car interior $37, \mathrm{~b}$ & Bagasse/PP & Talc/PP & $-20 \%$ & $-22 \%$ & $-21 \%$ \\
\hline \multirow[t]{2}{*}{ Car door ${ }^{34}$} & \multirow[t]{2}{*}{ GF/PP } & Steel & $-31 \%$ & $-59 \%$ & $+2 \%$ \\
\hline & & Aluminum & $+25 \%$ & $-87 \%$ & $-74 \%$ \\
\hline \multirow[t]{2}{*}{ Rear body of truck ${ }^{30}$} & \multirow[t]{2}{*}{ GF/PES } & Steel & $-44 \%$ & $-20 \%$ & \multirow[t]{2}{*}{ NA } \\
\hline & & Aluminum & $+11 \%$ & $-44 \%$ & \\
\hline \multirow[t]{3}{*}{ Closure panel $\left.\right|^{55, c}$} & \multirow[t]{3}{*}{ CF/EP } & Steel & $-60 \%$ & $+280 \%$ & $+41 \%$ \\
\hline & & Aluminum & $-27 \%$ & $-65 \%$ & $-54 \%$ \\
\hline & & GF/PET & $-42 \%$ & $+127 \%$ & $+116 \%$ \\
\hline Sedan $^{33}$ & CF/EP (virgin) & Steel & $-38 \%$ & $+30 \%$ & NA \\
\hline \multirow[t]{2}{*}{ Propeller shaft56,d } & \multirow[t]{2}{*}{ GFCF/EP } & Steel & $-63.5 \%$ & $-13 \%$ & \multirow[t]{2}{*}{ NA } \\
\hline & & Aluminum & $-55 \%$ & $-83 \%$ & \\
\hline Car floor pan ${ }^{31}$ & CNF/PP or CNF/PES & Steel & $-18.9 \%$ to $-61.2 \%$ & $+30 \%$ to $+1000 \%$ & NA \\
\hline Car floor pan ${ }^{8, e}$ & CFRP & Steel & $-17 \%$ & $+363 \%$ to $+412 \%$ & $+136 \%$ to $+219 \%$ \\
\hline
\end{tabular}

NA, not available.

Acronyms: ABS, poly(acrylonitrile butadiene styrene); CF, carbon fiber; CFRP, carbon-fiber-reinforced polymer; CNF, carbon nanofiber; EP, epoxy; GF, glass fiber; PES, polyester; PET, poly(ethylene terephthalate); PP, polypropylene.

a Energy for maintenance not included because of high estimated uncertainty. S235J0 or S355J0 for structural steel, X2CrNi18-11 or X2CrNiM018-14-3 for stainless steel, AlMgSi1,0F31 for aluminum, B35 for concrete.

b $50 \%$ content of recycled polypropylene

${ }^{c}$ Closure panels of a midsize passenger car consisting of four doors, hood, and deck lid; $11 \%$ content of recycled aluminum.

'STAM735H for steel, modified 6061-T8 for aluminum.

e CFRP contains polyacrylonitrile- and lignin-based carbon fibers obtained by sheet molding or powdering manufacturing methods.

energy consumption is proportional to weight to the power of $2 / 3$ within a specific velocity range. ${ }^{85}$ The energy savings induced by a certain amount of weight reduction by FRPs for a specific type of vehicle are more robust and widely adopted in LCA studies

Table III lists changes in CED values and GHG emissions during the use phase of a vehicle that can be obtained by using composites in place of traditional materials. CFRPs generally show dramatic energy savings compared to steel, aluminum, and even GFRPs, by virtue of the significant weight savings they make possible. NFRPs, such as bagasse/ polypropylene (PP) and china reed/PP, contribute to further weight reductions and energy savings compared to GFRPs. A crucial assumption is that the useful life of NFRPs will be the same as or comparable to that of traditional composites, but in fact little is known about the long-term durability of these materials, which is mostly determined by the moisture level in the composite. ${ }^{71}$ A systematic, quantitative analysis of the useful life of bio-based composites has not yet been performed.

\section{End-of-life phase}

Different end-of-life (EOL) scenarios lead to different impacts. Table IV provides an overview of CED values and GHG emissions for different EOL options. Recycling methods in Table IV include mechanical recycling for sheet-molding-compound composites and glass-mat-reinforced thermoplastics (GMTs), thermal treatment for CFRPs to recover carbon fibers, and remelting and recasting of steel and aluminum. Because the secondary use of the recycled materials is not clear, the environmental credits from recycling are not included in this table.

Landfills once were the common disposal approach for composite components. However, landfilling requires large 
Table III. Changes in cumulative energy demand (CED) and greenhouse-gas (GHG) emissions during the use phase for different material combinations.

\begin{tabular}{|c|c|c|c|c|c|}
\hline Product & $\begin{array}{l}\text { Composite } \\
\text { materials }\end{array}$ & $\begin{array}{l}\text { Substituted } \\
\text { materials }\end{array}$ & Lifetime (km) & $\begin{array}{l}\text { CED change } \\
\text { (GJ/piece) }\end{array}$ & $\begin{array}{l}\text { GHG change (kg } \\
\text { of } \mathrm{CO}_{2} \mathrm{e} / \text { piece) }\end{array}$ \\
\hline Car interior ${ }^{37}$ & Bagasse/PP & Talc/PP & 150000 & -19.3 & -206 \\
\hline $\begin{array}{r}\text { Transport } \\
\text { pallet }^{32}\end{array}$ & China reed/PP & GF/PP & $5000-200000$ & -0.6 to -2.3 & NA \\
\hline \multirow[t]{2}{*}{ Propeller shaft ${ }^{56}$} & \multirow[t]{2}{*}{$\mathrm{CF}$ and GF/EP } & Steel & \multirow[t]{2}{*}{150000} & -3.7 & -227 \\
\hline & & Aluminum & & -2.5 & -158 \\
\hline \multirow{3}{*}{$\begin{array}{l}\text { Closure panel of } \\
\operatorname{car}^{55, a}\end{array}$} & \multirow[t]{3}{*}{ CF/EP } & Steel & \multirow[t]{3}{*}{200000} & -26.9 & -2096 \\
\hline & & Aluminum & & -6.8 & -531 \\
\hline & & GF/PET & & -13.1 & -1023 \\
\hline \multirow[t]{2}{*}{ Car door ${ }^{34}$} & \multirow[t]{2}{*}{ GF/PP } & Steel & \multirow[t]{2}{*}{150000} & -2.0 & -150 \\
\hline & & Aluminum & & +0.8 & +67 \\
\hline \multirow{2}{*}{$\begin{array}{l}\text { Rear body of } \\
\text { truck }^{30}\end{array}$} & \multirow[t]{2}{*}{ GF/PES } & Steel Aluminum & \multirow[t]{2}{*}{190000} & -181 & NA \\
\hline & & Aluminum & & +23 & NA \\
\hline
\end{tabular}

NA, not available.

Acronyms: CF, carbon fiber; EP, epoxy; GF, glass fiber; PES, polyester; PET, poly(ethylene terephthalate); PP, polypropylene. a Closure panels of a midsized passenger car consisting of four doors, hood, and deck lid.

areas of land and does not allow for the recovery of the embodied energy of composites. Furthermore, waste typically must still undergo pretreatment to reduce its volume and hazardous effects before being landfilled. ${ }^{91}$

In most cases, FRPs are incinerated, for instance, in cement kilns, to recover embodied energy. A model for calculating the energy recovery from incineration of CFRPs was derived assuming complete conversion of carbon fibers and the polymer matrix into $\mathrm{CO}_{2}, \mathrm{H}_{2} \mathrm{O}$, and $\mathrm{N}_{2} \mathrm{O}$ by means of the modified Dulong formula: ${ }^{2}$

$$
\mathrm{TE}=337 C+1419(H-0.125 O)+93 S+23 N
$$

where TE, the total energy, is expressed in kilojoules per kilogram and $C, H, O, S$, and $N$ are the weight fractions, in percentages, of the corresponding elements. Glass-fiber-reinforced

composites can also be incinerated, but the incombustible glass fibers hinder the incineration, consuming $\sim 1.7 \mathrm{MJ}$ per kilogram of glass-fiber content. ${ }^{53}$

Through incineration, for example, burning composite scrap in cement kilns, one can not only recover the embodied energy, but incorporate the incombustible parts, such as glass fibers or mineral fillers, into cement production..$^{93}$ Incineration is also a logical way to dispose of NFRPs. Unlike glass fibers, natural fibers are combustible and therefore contribute to a higher heating value of components for incineration.

The four main recycling methods for $\mathrm{FRPs}^{94}$ are mechanical recycling, pyrolysis, fluidized-bed processing, and chemical treatment. Mechanical recycling is used for both GFRPs $^{93}$ and CFRPs ${ }^{95}$ but is mainly applied to GFRPs. It does not recover individual fibers. Instead, mechanical recycling is performed at the composite level ${ }^{94}$ and involves shredding, crushing, or milling FRPs and then separating the crushed pieces into fiber-rich and resin-rich fractions. These fractions are incorporated into new composites as fillers or reinforcements or used directly in the construction industry. ${ }^{93}$

The mechanical properties of FRPs containing recyclates can be severely affected. Depending on the content of recyclates (5-70\% by weight), flexural-strength reductions of $10-54 \%$ have been recorded ${ }^{96-98}$ As a result of these degraded mechanical properties, FRP recyclates are usually used in low-end applications such as construction fillers, which is best considered downcycling.

Other recycling meth-

Table IV. Environmental impacts of different types of composites under different end-of-life scenarios.

\begin{tabular}{|c|c|c|c|c|c|c|}
\hline & \multicolumn{2}{|c|}{ Landfill } & \multicolumn{2}{|c|}{ Recycling } & \multicolumn{2}{|c|}{$\begin{array}{l}\text { Incineration with } \\
\text { energy recovery }\end{array}$} \\
\hline & $\begin{array}{c}\text { CED } \\
(\mathrm{MJ} / \mathrm{kg})\end{array}$ & $\begin{array}{c}\mathrm{GHG} \\
\left(\mathrm{kg} \mathrm{of} \mathrm{CO}_{2} \mathrm{e} / \mathrm{kg}\right)\end{array}$ & $\begin{array}{l}\text { CED } \\
(\mathrm{MJ} / \mathrm{kg})\end{array}$ & 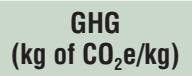 & $\begin{array}{c}\text { CED } \\
(\mathrm{MJ} / \mathrm{kg})\end{array}$ & $\begin{array}{c}\mathrm{GHG} \\
\left(\mathrm{kg} \mathrm{of} \mathrm{CO}_{2} \mathrm{e} / \mathrm{kg}\right)\end{array}$ \\
\hline SMC & NA & NA & $7^{86}$ & $0.4^{86}$ & $-7.5^{87}$ & $0.9^{87}$ \\
\hline GMT & $0.09^{34,55}$ & $0-0.02^{34,55}$ & $11^{186}$ & $0.9^{86}$ & $-25.2^{87}$ & $1.9^{87}$ \\
\hline CFRP & $0.11^{15}$ & $0.02^{55}$ & $10-15^{34,41}$ & NA & -31.7 to $-34^{87,88}$ & $3.2-3.4^{87,88}$ \\
\hline NFRP & NA & NA & NA & NA & -12 to $-34^{32,37,39,87}$ & $2.3-2.9^{37,87}$ \\
\hline Steel & NA & NA & $11.7-19.2^{89}$ & $0.5-1.2^{89}$ & NA & NA \\
\hline Aluminum & NA & NA & $2.4-5.0^{90}$ & $0.3-0.6^{90}$ & NA & NA \\
\hline
\end{tabular}

NA, not available.

Acronyms: SMC, sheet-molding-compound composites (e.g., glass-fiber-reinforced polyester resins); GMT, glass-mat-reinforced thermoplastics (e.g., glass-fiber-mat-reinforced polypropylene). ods, such as pyrolysis, ${ }^{93,99,100}$ the fluidized-bed process, ${ }^{93,94}$ and chemical processing, ${ }^{94,101}$ aim to reclaim individual fibers in CFRPs or GFRPs. The mechanical properties of carbon fibers can be retained at relatively high levels after pyrolysis $^{99,102-104}$ and chemical recycling. ${ }^{102}$ Glass fibers recycled by pyrolysis suffer a significant reduction in tensile strength as the pyrolysis temperature 
increases from $650^{\circ} \mathrm{C}$ to $800^{\circ} \mathrm{C} .{ }^{105}$ In the fluidized-bed process, glass fibers suffer a $50-90 \%$ reduction in strength, depending on processing temperature. ${ }^{93}$ The tensile strength of recycled carbon fibers also decreases sharply (by 20-34\%), whereas the elastic modulus remains stable. ${ }^{106,107}$

From an environmental perspective, pyrolysis generally consumes $2.8 \mathrm{MJ}$ of energy per kilogram, while providing liquefied petroleum gas $(\sim 2 \mathrm{MJ} / \mathrm{kg})$, heating fuel oil $(9.2 \mathrm{MJ} / \mathrm{kg})$, and composite fillers $(\sim 10.6 \mathrm{MJ} / \mathrm{kg})$. Thus, compared to EOL scenarios without recycling, a net energy retrieval of approximately $19 \mathrm{MJ} / \mathrm{kg}$ can be achieved. ${ }^{30}$

NFRP composites are recycled through multiple mechanical and thermal reprocessing procedures ${ }^{108-110}$ and generally retain their mechanical properties. For example, after seven cycles, the tensile modulus and tensile strength for a sisal fiber/PP NFRP were found to drop by only $10.1 \%$ and $17.2 \%$, respectively, in contrast to $40.1 \%$ and $52.5 \%$ losses in a glass fiber/PP GFRP. ${ }^{110}$ However, the process temperatures cannot exceed $200^{\circ} \mathrm{C}$ during NFRP recycling without degradation of the structural properties. ${ }^{111,112}$ This might make recycling of NFRPs impractical for matrixes that require high temperatures, for instance, to achieve remelting.

A seemingly attractive way to dispose of bio-based composite waste is biodegradation (anaerobic digestion or composting). Biodegradation mechanisms for typical bio-based composites, including natural-fiber-reinforced starch-based composites, ${ }^{113,114}$ natural-fiber-reinforced PLA, ${ }^{115,116}$ PHA-based bio-based composites, ${ }^{117,118}$ and blends of these polymers, ${ }^{119,120}$ have been comprehensively investigated.

An important concern for biodegradation is whether the process itself or its products exhibit ecotoxicity, which can be measured with microorganisms, soil fauna, and terrestrial plants. ${ }^{121}$ Initial studies support ecological safety of biodegradation for starch blends, ${ }^{122}$ cellulose-fiber-reinforced starch composite, ${ }^{123}$ and lactic-acid-based polymers that do not contain the connecting agent 1,4-butane diisocyanate. ${ }^{124}$ Although quantitative LCA studies of biodegradation are rare, one such study reported that composting and incineration are comparable in terms of GHG emissions, but incineration provides significantly higher nonrenewable energy recovery. ${ }^{125}$

\section{Life-cycle tradeoffs}

The preceding sections highlighted potential environmental impacts and benefits related to a switch to composites. However, increases in environmental impacts during one life-cycle phase can be compensated by reductions during another phase. This section illustrates such tradeoffs using three examples.

\section{GFRP versus steel and aluminum in transportation vehicles}

Two studies ${ }^{30,34}$ reported that GFRPs are environmentally beneficial compared to steel for interior panels and doors in automobiles (20\% and 59\% CED reductions for GF/PES and GF/PP, respectively) in both the production and use phases because of their lower weights. The environmental problem lies in the EOL phase. Mechanical recycling of GFRPs severely damages their intrinsic properties, and the incineration potential of GFRPs is also limited because of their relatively low heating value and high ash content. ${ }^{30}$

In contrast, making components from aluminum instead of GFRPs results in slightly lighter structures. Even though virgin aluminum consumes more energy during production, it is easily recycled, so that designers can substantially reduce energy demand by using recycled aluminum. In general, ${ }^{34}$ therefore, aluminum is better for these uses than GFRPs, from a full life-cycle perspective.

\section{CFRP versus steel and aluminum in transportation vehicles}

A graphical comparison of the environmental impacts of using CFRPs and steel in automobiles is presented in Figure 3 as an example. Quantitative information on various contributions to the production-phase impact of shifting from steel to CFRPs can be found in Table II. In the EOL stage, incineration of CFRPs will provide energy credits, but the overall EOL ecological impact is still negative (positive ecopoint values) because of $\mathrm{CO}_{2}, \mathrm{NO}_{x}$, and $\mathrm{SO}_{2}$ emissions ${ }^{88}$ In contrast, steel can be almost $100 \%$ recycled, with relatively low energy consumption and without degrading its materials properties, resulting in a comparatively beneficial EOL environmental impact. However, beyond a certain breakeven point in mileage, the environmental benefits of weight reduction in the use stage will overcome the negative impacts of CFRPs in the production and EOL stages. ${ }^{126}$ In one analysis, the breakeven point was found to be $132,000 \mathrm{~km}$ for CFRP versus steel for automotive panels, as shown in Figure 3. ${ }^{126}$

Such a breakeven point can also be determined for CFRPs compared to aluminum. An LCA comparison found that, if both the production and EOL stages are taken into account, an aluminum-based plane panel contributes fewer ecopoints (2 Pt) than a CFRP panel (10 Pt), because

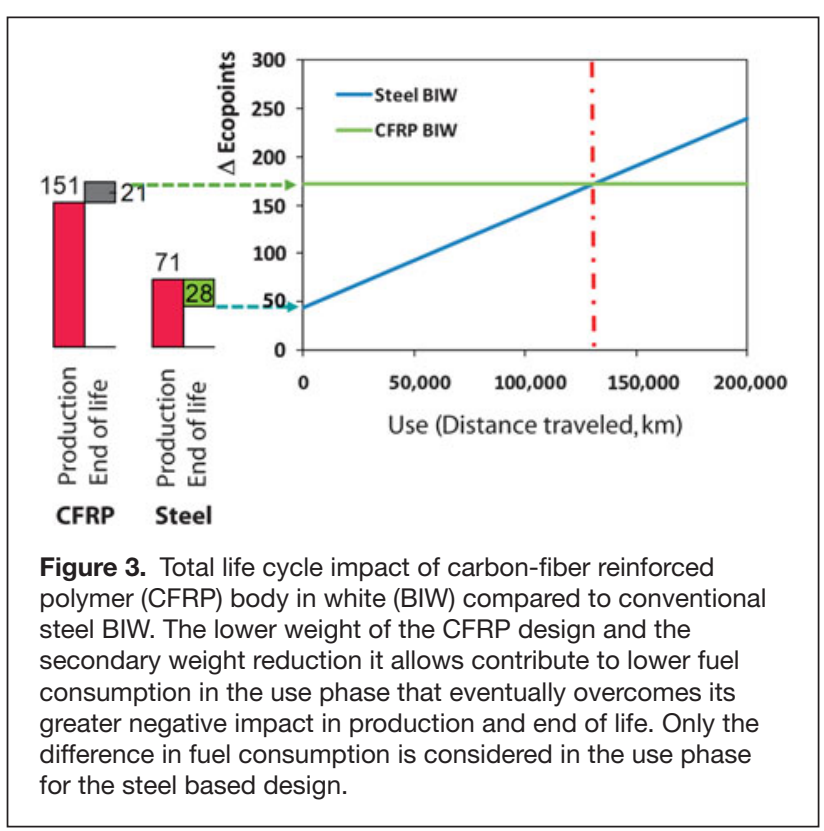


Table V. Comparison of cumulative energy demand (CED) values for natural-fiber-reinforced polymers (NFRPs) and glass-fiber-reinforced polymers (GFRPs).

\begin{tabular}{|c|c|c|c|c|c|}
\hline \multicolumn{1}{|c|}{ Product } & NFRP & $\begin{array}{c}\text { Substituted } \\
\text { material }\end{array}$ & $\begin{array}{c}\text { Production } \\
\text { phase }\end{array}$ & Use phase & EOL phase \\
\hline $\begin{array}{c}\text { Side panel of } \\
\text { light car }\end{array}$ & Hemp/EP & ABS & -59 & -71 & +27 \\
\hline $\begin{array}{c}\text { Side panel of } \\
\text { heavy car }\end{array}$ & Hemp/EP & ABS & -59 & -118 & +27 \\
\hline Car interior ${ }^{37, b}$ & Bagasse/PP & Talc/PP & -222 & -19313 & +62.3 \\
\hline
\end{tabular}

${ }^{a}$ Component consists of $820 \mathrm{~g}$ of hemp/epoxy (EP) versus $1125 \mathrm{~g}$ of poly(acrylonitrile butadiene styrene). Distance of use is $200,000 \mathrm{~km}$.

${ }^{b}$ Component consists of $20 \mathrm{~kg}$ of bagasse/polypropylene (PP) versus $25 \mathrm{~kg}$ of glass fiber (GF)/PP. Distance of use is $150,000 \mathrm{~km}$. End-of-life (EOL) phase is $50 \%$ recycling and $50 \%$ incineration with energy recovery.

aluminum can also be easily recycled. ${ }^{84}$ Because of the significant weight reduction, the ecopoint breakeven point for CFRP versus aluminum in aircraft applications is only $70,000 \mathrm{~km}$ of flight. ${ }^{84}$

\section{NFRP versus GFRP in transportation vehicles}

Table $\mathbf{V}$ compares the CED values of NFRPs and GFRPs during the different life-cycle phases. The EOL scenario for all three listed cases involves incineration with energy recovery. Compared to GFRPs, NFRPs typically provide fewer energy credits in the EOL phase because of the lower equivalent product mass generally required for NFRP-based product designs, resulting in less material to be burned. NFRPs, however, provide favorable CED scores during both the production and use phases, which results in significantly reduced CED values for the total life cycle. The main environmental concerns for NFRPs, particularly biobased polymers/natural fibers, are emissions of nitrogen and phosphorus during cultivation, ${ }^{127}$ large arable-land requirements, ${ }^{128,129}$ and ecosystem deterioration. ${ }^{127,129}$ Presently, these impacts are too uncertain to be included in LCA studies, ${ }^{127}$ and more data on the production-phase impacts of NFRPs are needed.

\section{Conclusions}

Comparison of the environmental performance of FRP composites with that of traditional material solutions at a product level requires a thorough analysis of the complete life cycle of the product. The production of matrix and fiber materials generates considerable environmental impacts, especially because of the energy intensity of carbon fiber production. End-of-life processing creates comparatively less impact and therefore does not dominate environmental tradeoff considerations.

Depending on the application, the environmental payback during the product-use phase can be substantial: In aerospace applications, for example, weight reductions and related energy savings clearly dominate the life-cycle assessment. For applications with less energy-intensive use phases, such as automotive structures, the tradeoff between environmental impacts caused during production and expected savings during use are less obvious and should be studied on a caseby-case basis.

According to the studied environmental impact evaluation criteria and the available data, when bio-based composites can provide the required material properties, they are valid alternatives with a reduced overall impact compared to traditional matrix and fiber materials. However, in terms of both further improving material properties and investigating environmental impacts, there is still significant scope for further research.

\section{Supplementary materials}

For supplementary materials for this article, please visit http:// dx.doi.org/10.1557/mrs.2012.33.

\section{References}

1. D.L. Chung, Composite Materials: Science and Applications (Springer, New York, ed. 2, 2010).

2. R.D. Anandjiwala, S. Blouw, J. Nat. Fibers 4, 91 (2007).

3. A.N. Netravali, S. Chabba, Mater. Today 6, 22 (2003).

4. F. Vilaplana, E. Strömberg, S. Karlsson, Polym. Degrad. Stab. 95, 2147 (2010).

5. D. Kellenberger, H.-J. Althaus, N. Jungbluth, T. Kunniger, M. Lehmann, P. Thalmann, Life Cycle Inventories of Building Products (Swiss Centre for Life Cycle Inventories, Dübendorf, Switzerland, 2007).

6. A. Subic, A. Mouritz, O. Troynikov, Sports Technol. 2, 67 (2009).

7. J. Takahashi, H. Zushi, T. Suzuki, H. Nagai, K. Kageyama, H. Yoshinari, in Proceedings of the 5th International Conference on EcoBalance (Society of NonTraditional Technology, Tsukuba, Japan, 2002), pp. 259-262.

8. S. Das, Int. J. Life Cycle Assessment 16, 268 (2011).

9. $\mathrm{LCl}$ values of carbon fiber (Japan Carbon Fiber Manufacturers Association, Tokyo, Japan, 2009).

10. V. Khanna, B.R. Bakshi, L.J. Lee, in Proceedings of the 2007 IEEE International Symposium on Electronics and the Environment (IEEE, New York, 2007), pp. 128-133.

11. A. Dowling, R. Clift, N. Grobert, D. Hutton, R. Oliver, 0. O’Neill, J. Pethica, N. Pidgeon, J. Porritt, J. Ryan, Nanoscience and nanotechnologies: opportunities and uncertainties (The Royal Society \& The Royal Academy of Engineering, London, 2004).

12. M.J. John, S. Thomas, Carbohydr. Polym. 71, 343 (2008).

13. A.K. Mohanty, M. Misra, G. Hinrichsen, Macromol. Mater. Eng. 276-277, 1 (2000).

14. P. Wambua, J. Ivens, I. Verpoest, Compos. Sci. Technol. 63, 1259 (2003).

15. H. Liu, F. Xie, L. Yu, L. Chen, L. Li, Prog. Polym. Sci. 34, 1348 (2009).

16. L. Avérous, P.J. Halley, Biofuels, Bioprod. Biorefin. 3, 329 (2009).

17. A.K. Mohanty, M. Misra, L.T. Drzal, Eds. Natural Fibers, Biopolymers, and Biocomposites (Taylor \& Francis, Boca Raton, FL, 2005).

18. K. Van de Velde, P. Kiekens, Polym. Test. 21, 433 (2002)

19. J.C. Ronda, G. Lligadas, M. Galià, V. Cádiz, Eur. J. Lipid Sci. Technol. 113, 46 (2011).

20. Y. Lu, R.C. Larock, ChemSusChem 2, 136 (2009).

21. D.D. Andjelkovic, M. Valverde, P. Henna, F. Li, R.C. Larock, Polymer $\mathbf{4 6}$ 9674 (2005).

22. M. Sacristán, J.C. Ronda, M. Galià, V. Cádiz, Polymer 51, 6099 (2010).

23. Y. Xia, R.C. Larock, Green Chem. 12, 1893 (2010).

24. M. Galià, L.M. de Espinosa, J.C. Ronda, G. Lligadas, V. Cádiz, Eur. J. Lipid Sci. Technol. 112, 87 (2010).

25. V. Sharma, P.P. Kundu, Prog. Polym. Sci. 33, 1199 (2008).

26. P. Czub, Polym. Adv. Technol. 20, 194 (2009).

27. M.A.J. Huijbregts, L.J.A. Rombouts, S. Hellweg, R. Frischknecht, A.J. Hendriks, D. van de Meent, A.M.J. Ragas, L. Reijnders, J. Struijs, Environ. Sci. Technol. 40, 641 (2005). 
28. Kyoto Protocol to the United Nations Framework Convention on Climate Change (UN Document FCCC/CP/1997/7/Add.1, Decision 1/CP.3, Annex 7, United Nations, New York, 1997).

29. M. Goedkoop, R. Heijungs, M. Huijbregts, A. De Schryver, J. Struijs, R. van Zelm, ReCiPe 2008, A life cycle impact assessment method which comprises harmonised category indicators at the midpoint and the endpoint level. Report I: Characterisation (VROM, The Hague, The Netherlands, 2009).

30. Y.S. Song, J.R. Youn, T.G. Gutowski, Composites A 40, 1257 (2009)

31. V. Khanna, B.R. Bakshi, L.J. Lee, in Proceedings of the 2008 IEEE International Symposium on Electronics and the Environment (IEEE, New York, 2008), pp. 1-6.

32. T. Corbière-Nicollier, B.G. Laban, L. Lundquist, Y. Leterrier, J.A.E. Månson, 0. Jolliet, Resour. Conserv. Recycl. 33, 267 (2001).

33. T. Suzuki, T. Odai, R. Hukui, J. Takahashi, paper presented at the International Conference on Life Cycle Assessment 2005, San Jose, Costa Rica, 25-28 April 2005.

34. P. Puri, P. Compston, V. Pantano, Int. J. Life Cycle Assessment 14, 420 (2009).

35. J. Diener, U. Siehler, Angew. Makromol. Chem. 272, 1 (1999)

36. O. De Vegt, W. Haije, Comparative Environmental Life Cycle Assessment of Composite Materials (Report ECN-I-97-050, Netherlands Energy Research Foundation, Petten, The Netherlands, 1997).

37. S.M. Luz, A. Caldeira-Pires, P.M.C. Ferrão, Resour. Conserv. Recycl. 54, 1135 (2010)

38. R.A. Daniel, paper presented at Lightweight Bridge Decks: European Bridge Engineering Conference, Rotterdam, The Netherlands, 27-28 March 2003.

39. K. Wötzel, R. Wirth, M. Flake, Angew. Makromol. Chem. 272, 121 (1999).

40. M. Pietrini, L. Roes, M.K. Patel, E. Chiellini, Biomacromolecules 8, 2210 (2007).

41. T. Suzuki, J. Takahashi, in 9th Japan International SAMPE Symposium \& Exhibition (JISSE-9) (SAMPE-Japan, Tokyo, Japan, 2005), pp. 14-19.

42. M. Patel, Energy 28, 721 (2003).

43. I. Boustead, Eco-profiles of the European Plastics Industry (Association of Polymer Manufacturers in Europe, Brussels, Belgium, 2005).

44. Ecolizer 2.0 (Openbare Vlaamse Afvalstoffenmaatschappij, Mechelen, Belgium, 2003-2011).

45. H. Kindler, A. Nikles, Kunststoffe 70, 802 (1980).

46. Environmental Production Declaration (EPD). MATER-BI NF Type: Biodegradable Plastic Pellets for Films, (Novamont, Novara, Italy, 2001).

47. E.T.H. Vink, S. Davies, J.J. Kolstad, Ind. Biotechnol. 6, 212 (2010).

48. T.U. Gerngross, Nat. Biotechnol. 17, 541 (1999).

49. M. Akiyama, T. Tsuge, Y. Doi, Polym. Degrad. Stab. 80, 183 (2003).

50. S. Kim, B. Dale, Int. J. Life Cycle Assessment 10, 200 (2005).

51. A. Diehlmann, G. Kreisel, Ökologische Bilanzierung ausgewählter Lackrohstoffe: Vergleich von Bindemitteln auf nativer und petrochemischer Basis (Jena University, Jena, Germany, 2000).

52. S. González-García, A. Hospido, G. Feijoo, M. Moreira, Resour. Conserv. Recycl. 54, 923 (2010).

53. L. Shen, M. Patel, J. Polym. Environ. 16, 154 (2008)

54. J.E.G.V. Dam, H.L. Bos, The Environmental Impact of Fibre Crops in Industrial Applications (Food and Agriculture Organization, Rome, Italy, 2004).

55. S.M. Schexnayder, S. Das, R. Dhingra, J.G. Overly, B.E. Tonn, J.H. Peretz, G. Waidley, G.A. Davis, Environmental Evaluation of New Generation Vehicles and Vehicle Components (Report ORNL/TM-2001-266, Oak Ridge National Laboratory, Oak Ridge, TN, 2001)

56. J. Kasai, JSAE Rev. 20, 387 (1999).

57. Sustainability of Fibre-Reinforced Plastics-An Assessment Based on Selected Examples of Application (Industrievereinigung Verstärkte Kunststoffe e.V., Frankfurt am Main, Germany, 2010).

58. D. Codd, Advanced, Lightweight Materials Development and Technology for Increasing Vehicle Efficiency (KVA Incorporated, Escondido, CA, 2008).

59. S. Das, The Cost of Automotive Polymer Composites: A Review and Assessment of DOE's Lightweight Materials Composites Research (Report ORNL/TM-2000/283, Oak Ridge National Laboratory, Oak Ridge, TN, 2001).

60. J. Batchelor, Mater. Des. 2, 172 (1981).

61. P. Noury, B. Hayman, D. McGeorge, J. Weitzenböck, paper presented at the 37th Western Europe Graduate Education Marine Technology Summer School, Madrid, Spain, 11-15 November 2002.

62. D. Gay, Composite Materials: Design and Applications (CRC Press, Boca Raton, FL, 2003).

63. B. Dahlke, H. Larbig, H.D. Scherzer, R. Poltrock, J. Cell. Plast. 34, 361 (1998). 64. T.G. Schuh, Renewable Materials for Automotive Applications (DaimlerChrysler AG, Stuttgart, Germany, 2000).

65. L.T. Drzal, paper presented at the 2001 SPE Automotive Composites Conference, Troy, MI, 19-20 September 2001.

66. R. Joffe, L. Wallström, L. Berglund, paper presented at the International Scientific Colloquium "Modelling for Saving Resources," Riga, Latvia, 17-18 May 2001.
67. M. Pervaiz, M.M. Sain, Macromol. Mater. Eng. 288, 553 (2003).

68. M.G. Kamath, G.S. Bhat, D.V. Parikh, D. Mueller, Int. Nonwovens J. 14 (1), 34 (2005).

69. J. Holbery, D. Houston, JOM 58, 80 (2006).

70. E. Mangino, J. Carruthers, G. Pitarresi, Int. J. Vehicle Des. 44, 211 (2007)

71. B. Svennerstedt, paper presented at the 9th International Conference on Durability of Building Materials and Components, Brisbane, Australia, 17-21 March 2002.

72. S.V. Joshi, L. Drzal, A. Mohanty, S. Arora, Composites A 35, 371 (2004).

73. F. Stodolsky, A. Vyas, R. Cuenca, paper presented at the Second World Car Conference, Riverside, CA, 22-24 January 1995.

74. I. Verpoest, T.C. Thanh, S. Lomov, in 9th Japan International SAMPE Symposium \& Exhibition (JISSE-9) (SAMPE-Japan, Tokyo, Japan, 2005), pp. 56-61.

75. TECABS: Technologies for Carbon Fibre Reinforced Modular Automotive Body Structures (Department of Metallurgy and Materials Engineering, Katholieke Universiteit Leuven, Leuven, Belgium), www.mtm.kuleuven.be/Onderzoek/ Composites/projects/finished_projects/ (accessed January 2012).

76. A.B. Lovins, D.R. Cramer, Int. J. Vehicle Des. 35, 50 (2004).

77. P.S. Castellan, I. Blanc, M.G. Ferrier, B. Caber, M. Wakeman, J.A. Manson, D. Emery, S.H. Han, J. Hong, O. Jolliet., Int. J. Life Cycle Assessment 14, 429 (2009).

78. C. Souris, Mater. Sci. Eng. A 412, 171 (2005).

79. K. Olofsson, G. Arnestad, A. Lönnö, A. Hedlund-Åström, T. Jansson, M. Hjortberg, paper presented at 13th European Conference of Composite Materials (ECCM-13), Stockholm, Sweden, 2-5 June 2008.

80. I. Stenius, A. Rosén, J. Kuttenkeuler, Mar. Struct. 24, 43 (2011).

81. D. Malen, K. Reddy, Preliminary Vehicle Mass Estimation Using Empirical Subsystem Influence Coefficients (Auto/Steel Partnership, University of Michigan, Ann Arbor, Ml, 2007)

82. T.C. Moore, paper presented at the 13th International Electric Vehicle Symposium (EVS-13), Osaka, Japan, 13-16 October 1996.

83. M. Bertram, K. Buxmann, P. Furrer, Int. J. Life Cycle Assessment 14, 62 (2009).

84. L. Scelsi, M. Bonner, A. Hodzic, C. Souris, C. Wilson, R. Scaife, K. Ridgway, eXPRESS Polym. Lett. 5, 209 (2011).

85. H. Helms, U. Lambrecht, Energy Saving by Light-Weighting II (Institute for Energy and Environmental Research, Heidelberg, Germany, 2004).

86. Y. Leterrier, in Comprehensive Composite Materials, K. Anthony, Z. Carl, Eds. (Pergamon, 0xford, UK, 2000), pp. 1073-1102.

87. A. Hedlund-Aström, Model for End of Life Treatment of Polymer Composite Materials (Royal Institute of Technology, Stockholm, Sweden, 2005).

88. J.R. Duflou, J. De Moor, I. Verpoest, W. Dewulf, CIRP Ann. 58, 9 (2009)

89. A Report on the Environmental Benefits of Recycling-A Critical Review of the Data for Steel (Bureau of International Recycling, Brussels, Belgium, 2010). 90. A Report on the Environmental Benefits of Recycling-A Critical Review of the Data for Aluminum (Bureau of International Recycling, Brussels, Belgium, 2010). 91. Council Directive 1999/31/EC of 26 April 1999 on landfill of waste, in Official Journal L 182, 16/07/1999 (European Commission, Brussels, Belgium, 1999).

92. G. Tchobanoglous, H. Theisen, S. Vigil, Integrated Solid Waste Management: Engineering Principles and Management Issues (McGraw-Hill, New York, 1993).

93. S.J. Pickering, Composites A 37, 1206 (2006).

94. S. Pimenta, S.T. Pinho, Waste Manage. 31, 378 (2011).

95. J. Takahashi, N. Matsutsuka, T. Okazumi, K. Uzawa, I. Ohsawa, K. Yamaguchi, A. Kitano, in 10th Japan International SAMPE Symposium \& Exhibition (JISSE-10) (SAMPE-Japan, Tokyo, Japan, 2007). pp.8-11.

96. R. Derosa, E. Telfeyan, J.S. Mayes, J. Thermoplastic Composite Mater. 18 219 (2005).

97. J.D. Diniz Melo, E.A. Dos Santos, J. Reinforced Plastics Composites 28 2459 (2009).

98. J. Palmer, Ph.D. thesis, University of Exeter, Exeter, Exeter, U.K., 2009

99. L.O. Meyer, K. Schulte, E. Grove-Nielsen, J. Compos. Mater. 43, 1121 (2009) 100. J. Gañan, J.F. González, C.M. González-García, E.M. Cuerda-Correa, A. Macías-García, Bioresour. Technol. 97, 711 (2006).

101. W. Dang, M. Kubouchi, H. Sembokuya, K. Tsuda, Polymer 46, 1905 (2005). 102. C.-K. Lee, Y.-K. Kim, P. Pruitichaiwiboon, J.-S. Kim, K.-M. Lee, C.-S. Ju, Transp. Res. D 15, 197 (2010).

103. E. Lester, S. Kingman, K.H. Wong, C. Rudd, S. Pickering, N. Hilal, Mater. Res. Bull. 39, 1549 (2004).

104. J.P. Heil, M.J. Hall, D.R. Litzenberger, R. Clearfield, J.J. Cuomo, P.E. George, W.L. Carberry, paper presented at SAMPE '09, Baltimore, MD, 18-21 May 2009. 105. A.M. Cunliffe, N. Jones, P.T. Williams, Environ. Technol. 24, 653 (2003). 106. G. Jiang, S.J. Pickering, G.S. Walker, K.H. Wong, C.D. Rudd, Appl. Surf. Sci. 254, 2588 (2008).

107. K.H. Wong, S.J. Pickering, T.A. Turner, N.A. Warrior, paper presented at Composites Innovation 2007-Improved Sustainability and Environmental Performance, Barcelona, Spain, 4-5 October 2007. 
108. V. Srebrenkoska, G.B. Gaceva, M. Avella, M.E. Errico, G. Gentile, Polym. Int. 57, 1252 (2008).

109. A. Le Duigou, I. Pillin, A. Bourmaud, P. Davies, C. Baley, Composites A 39, 1471 (2008).

110. A. Bourmaud, C. Baley, Polym. Degrad. Stab. 92, 1034 (2007).

111. G. Marsh, Mater. Today 6, 36 (2003).

112. F.P. La Mantia, M. Morreale, Composites A 42, 579 (2011).

113. R.P. Singh, J.K. Pandey, D. Rutot, P. Degée, P. Dubois, Carbohydr. Res. 338, 1759 (2003)

114. C.R. di Franco, V.P. Cyras, J.P. Busalmen, R.A. Ruseckaite, A. Vázquez, Polym. Degrad. Stab. 86, 95 (2004).

115. D. Plackett, T. Løgstrup Andersen, W. Batsberg Pedersen, L. Nielsen, Compos. Sci. Technol. 63, 1287 (2003)

116. R. Kumar, M. Yakubu, R. Anandjiwala, eXPRESS Polym. Lett. 4, 423 (2010).

117. N.M. Barkoula, S.K. Garkhail, T. Peijs, Ind. Crops Prod. 31, 34 (2010).

118. G.R. Saad, H. Seliger, Polym. Degrad. Stab. 83, 101 (2004).

119. T. Ohkita, S.-H. Lee, J. Appl. Polym. Sci. 100, 3009 (2006).

120. L. Yu, K. Dean, L. Li, Prog. Polym. Sci. 31, 576 (2006).

121. A. Kapanen, M. Itävaara, Ecotoxicol. Environ. Saf. 49, 1 (2001).
122. R. Jayasekara, S. Sheridan, E. Lourbakos, H. Beh, G.B.Y. Christie, M. Jenkins, P.B. Halley, S. McGlashan, G.T. Lonergan, Int. Biodeterior. Biodegrad. 51, 77 (2003).

123. E. Rudnik, N. Milanov, G. Matuschek, A. Kettrup, Chemosphere 70, 337 (2007).

124. J. Tuominen, J. Kylmä, A. Kapanen, O. Venelampi, M. Itävaara, J. Seppälä, Biomacromolecules 3, 445 (2002).

125. B.G. Hermann, L. Debeer, B. De Wilde, K. Blok, M.K. Patel, Polym. Degrad. Stab. 96 (6), 1159 (2011)

126. K. Van Acker, I. Verpoest, J. De Moor, J.-R. Duflou, W. Dewulf, Rev. Met Paris, 541 (2009).

127. S.A. Miller, A.E. Landis, T.L. Theis, Environ. Sci. Technol. 41, 5176 (2007).

128. V. Piemonte, F. Gironi, Environ. Prog. Sustainable Energy 30 (3), 459 (2010). 129. Y. Deng, K. Van Acker, W. Dewulf, J.R. Duflou, in Glocalized Solutions for Sustainability in Manufacturing: Proceedings of the 18th CIRP International Conference on Life Cycle Engineering, Technische Universität Braunschweig, Braunschweig, Germany, May 2nd-4th, 2011, J. Hesselbach, C. Herrmann, Eds. (Springer, New York, 2011); pp. 605-610.

\section{The 2012 MRS Spring Meeting Isn't Over Yet!}

This was our biggest Spring Meeting yet, and now you can view selected talks and lectures, complete with slides, from the comfort of your home or office, or on the go!

The following presentations are available on the MRS website as video broadcasts.

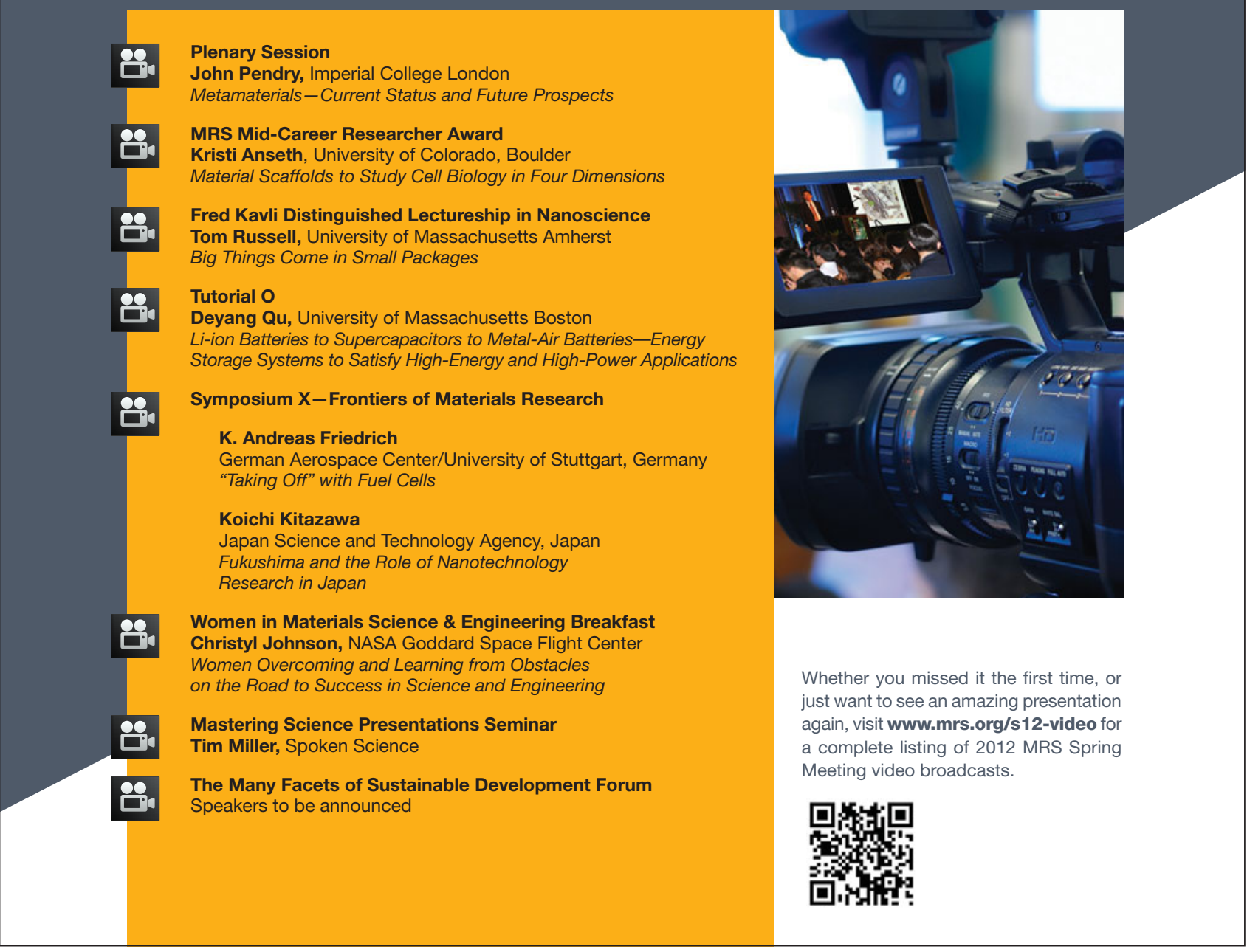

